\title{
A Prospective Study to Correlate Preoperative Serum Albumin as a Predictor of Post-Operative Mortality and Morbidity
}

\author{
Sagar Dilip Rathod ${ }^{1}$, Dhirendra D. Wagh ${ }^{2}$ \\ 1,2 Department of General Surgery, Datta Meghe Institute of Medical Sciences, \\ (Deemed to Be University), Sawangi (M), Wardha, Maharashtra, India.
}

\section{ABSTRACT}

\section{BACKGROUND}

In recent times serum albumin has been considered as a very important factor in determining the clinical outcome of a patient undergoing major surgery. Patients with low serum albumin pre-operatively have been encountered with poor outcome postoperatively. This study was conducted to assess the association between serum albumin concentration and postoperative outcome (morbidity / mortality).

\section{METHODS}

This prospective observational study was carried out in JNMC and AVBRH, Sawangi, Wardha, from September 2018 to September 2020. All patients undergoing emergency / elective major surgeries were included in the study. Detailed history of patients was recorded including chief complaints and any other previous medical history.

\section{RESULTS}

104 patients were included in the study of which maximum number of patients were seen in the age range of $35-64$ years. The mean age being $48.19 \pm 15.60$ years. The gender distribution with more male predominance with $59.62 \%$ participants being males and $40.38 \%$ participants being females. Total 68 patients had postoperative complications, 40 being males and 28 being females. Highest number of complications in this study were seen in age group 55 - 64 years. 50 out of 73 patients with benign diseases developed complications and 18 out of 31 patients with malignant diseases developed complications.

\section{CONCLUSIONS}

Serum albumin has become an important modality to define the clinical outcome of a patient. Surgeons have started using it as a marker to define the post-operative outcome of a patient undergoing surgery. Exogenous albumin administration has also showed promising results in improving the outcome of a patient in the post-operative period.

\section{KEY WORDS}

Hypoalbuminaemia, Serum Albumin, Postoperative Mortality, Postoperative Morbidity
Corresponding Author: Dr. Sagar Dilip Rathod, Department of Surgery, Datta Meghe Institute of Medical Sciences, (Deemed to Be University), Sawangi (M), Wardha - 442001, Maharashtra, India.

E-mail: sagarrr9@gmail.com

DOI: $10.14260 /$ jemds/2021/273

How to Cite This Article:

Rathod SD, Wagh DD A prospective study to correlate preoperative serum albumin as a predictor of post-operative mortality and morbidity. J Evolution Med Dent Sci 2021;10(18):1291-1295, DOI: 10.14260/jemds/2021/273

Submission 07-10-2020,

Peer Review 29-01-2021,

Acceptance 06-02-2021,

Published 03-05-2021.

Copyright (C) 2021 Sagar Dilip Rathod et al. This is an open access article distributed under Creative Commons Attribution License [Attribution 4.0 International (CC $B Y 4.0)]$ 


\section{BACKGROUND}

Human serum albumin has been claimed in literature to be an important factor in determining the nutritional status of the patient. Earliest reports of 1500 A.D. were suggestive of excretion of albumin in urine. Clinical use of serum albumin has been noted as early as 1940 s. During the attack on Pearl Harbour, severely wounded patients were administered with purified human albumin by I.S. Ravdin (surgeon by profession). ${ }^{1}$

Paul D. Boyer quoted concentrated serum albumin fractionated from blood plasma was effective in the management of shock in the battlefield during war.

Human albumin is synthesised and secreted from the liver. Human serum albumin is translated as preproalbumin from a single gene. The protein in taken in endoplasmic reticulum and then transported to Golgi bodies after the N-terminal prepropeptide is cleaved by serine protease. The final secretory molecular weight of human albumin being 66,700 daltons. Human serum albumin has three homologous domains over nine double loops. They are termed I, II \& III. Each domain has two sub-domains named A \& B. The architecture mainly composed of sub-domains facilitates in endogenous \& exogenous ligand binding.

Human albumin has a major role in determining the plasma oncotic pressure, ${ }^{2}$ so much so that it provides $80 \%$ of the oncotic pressure of the plasma, ${ }^{3}$ ligands are bounded and transported by albumin, hence decreasing the free plasma concentration of various substances in the plasma. Albumin binds to both positive and negative charged substances including organic anions. Important compounds that are bound to albumin are various drugs, vitamin D, thyroxin, bile acids, zinc, copper etc. Organic anions that are bound by albumin are bilirubin, magnesium and long chained fatty acids. By binding to albumin the overall plasma concentration of the free compounds decrease and so does the clearance of the compounds from the body is decreased. Binding to albumin also limits the biologic activity of the various compounds. ${ }^{3}$

Initially, serum albumin was highly misunderstood and the vital importance of serum albumin in determining the nutritional makeup of a person was not appreciated. It took biochemists and physicians a long time to understand its importance. In the $20^{\text {th }}$ century, its importance was noted in the 1945, during the various battles, albumin became in great demand by almost every medical practitioner in the battlefield to treat the wounded soldiers. It became widely available throughout the pharmacies. It was supplied in $25 \% \mathrm{w} / \mathrm{v}$ form and became widely popular among surgeons and nutritionists after the war. Currently albumin is available in the form of 4 $\%, 5 \%, 20 \%$ and $25 \% \mathrm{w} / \mathrm{v}$ and can be stored at $<30 \mathrm{C}$, making it easier to administer and store.

Clinically exogenous albumin infusion is not only used by surgeons but is also widely used by intensivist and physicians in patients with state of hypoproteinaemia (such as liver failure, burns, septicaemia, cirrhosis etc.)

Serum albumin can be used as a marker of malnutrition and is a better marker then body mass index (BMI) as serum albumin estimation is fast and the test is readily available. Serum albumin levels of $>3.5 \mathrm{gm} / \mathrm{dL}$ is taken to be adequate store of serum albumin and provides protection from many destructive biological mechanisms. Many studies have shown the poor clinical outcomes of patient with low serum albumin levels $[<3.5 \mathrm{gm} / \mathrm{dL}] .4$

More recently a study published by Gassa A et al. ${ }^{5}$ conducted on patients undergoing transcatheter aortic valve replacement (TAVR) concluded that, preoperative hypoalbuminaemia [serum albumin levels $<3.5 \mathrm{gm} / \mathrm{dL}$ ] in patients undergoing TAVR is a good indicator to predict postoperative morbidity or mortality.

At present there are many studies which show the importance of serum albumin, are only present in literature, but only few studies show the importance of serum albumin in hospital setting and how serum albumin levels have an overall impact on determining the postoperative outcome of patient. Also, few studies are present which determine the effect of exogenous albumin transfusion (preoperatively or postoperatively) on overall postoperative outcome of the patient. So, with current study we want to add the evidencebased observations, which clearly concludes the impact of preoperative serum albumin on determining postoperative morbidity or mortality.

\section{Objectives:}

1. To study the effect of preoperative level of serum albumin, diabetic status, sepsis status and its effect on post-operative outcome.

2. To compare the effect of preoperative correction of serum proteins, diabetes mellitus and sepsis to postoperative correction and post-operative outcome.

3. To study the outcome of the cases where serum albumin, diabetes status and sepsis status could not be corrected.

\section{METHODS}

The prospective observational study was carried out in JNMC and AVBRH, Sawangi, Wardha from September 2018 to September 2020. All patients undergoing emergency / elective major surgeries were included in the study. Detailed history of patients was recorded including chief complaints and any previous medical history. Clinical diagnoses of all the patients were recorded. Initial blood investigations were done, BMI of patient was calculated. Any comorbidities of the involved patients were noted. Baseline (pre-operative) serum albumin levels were noted. Patient were categorised on the basis of type of surgery (elective / emergency). Postoperative serum albumin levels were recorded on POD (post-operative day) 0 [immediate post-operatively], POD 2 \& POD 4. Patients were also categorised in those receiving preoperative exogenous albumin transfusion and postoperative exogenous albumin transfusion.

\section{Inclusion Criteria}

All patients likely to undergo major elective / emergency surgical interventions in General Surgery, CVTS and Neurosurgery were included in the study.

\section{Exclusion Criteria}

1. Patient not operated in last 30 days were excluded from the study. 
2. Raised serum bilirubin level and abnormal kidney function tests (KFT) were excluded.

\section{Statistical Analysis}

The recorded observations were studied in the form of table, graphs and P-value was calculated by using Statistical Package for the Social Sciences (SPSS) software, version 24 \& statistical data was recorded and calculated by SPSS Version 24 .

\section{RESULTS}

\begin{tabular}{|ccc|}
\hline Age Group (yrs.) & No. of Patients & Percentage \\
\hline $15-24$ yrs. & 7 & 6.73 \\
$25-34$ yrs. & 11 & 10.58 \\
$35-44$ yrs. & 22 & 21.15 \\
$45-54$ yrs. & 22 & 21.15 \\
$55-64$ yrs. & 22 & 21.15 \\
$65-74$ yrs. & 12 & 11.54 \\
$\geq 75$ yrs. & 8 & 7.69 \\
Total & 104 & 100 \\
\hline Mean \pm SD & $48.19 \pm 15.60$ (15 - 87 years) \\
\hline Table 1. Age Wise Distribution of Patients \\
\hline \multicolumn{2}{|c}{} \\
\hline
\end{tabular}

In the present study, it was observed that the mean age of presentation was $48.19 \pm 15.60$ (15 - 87 years), the youngest patient being 15 years old and oldest patient being 87 years old.

\begin{tabular}{|ccc|}
\hline Gender & No. of Patients & Percentage \\
\hline Male & 62 & 59.62 \\
Female & 42 & 40.38 \\
Total & 104 & 100 \\
\hline \multicolumn{2}{|c|}{ Table 2. Gender Wise Distribution of Patients } \\
\hline
\end{tabular}

In this study, it was observed that out of 104 cases studied, $62(59.62 \%)$ were male patients and 42 (40.38\%) were female patients. The gender profiling showed a male to female ratio of 1.47: 1 .

\begin{tabular}{|cccc|}
\hline Gender & $\begin{array}{c}\text { Complications } \\
\text { Present }\end{array}$ & $\begin{array}{c}\text { Complications } \\
\text { Absent }\end{array}$ & Total \\
\hline Male & $40(38.46 \%)$ & $22(21.15 \%)$ & $62(59.62 \%)$ \\
Female & $28(26.92 \%)$ & $14(13.46 \%)$ & $42(40.38 \%)$ \\
Total & $68(65.38 \%)$ & $36(34.62 \%)$ & 104 \\
$\chi 2$-value & \multicolumn{3}{|c}{$0.05, \mathrm{P}=0.82, \mathrm{NS}, \mathrm{P}>0.05$} \\
\hline Table 3. Gender Wise Distribution of Complications of the Patients \\
\hline \multicolumn{4}{r}{}
\end{tabular}

\begin{tabular}{|c|c|c|c|}
\hline Age (yrs.) & $\begin{array}{c}\text { Complications } \\
\text { Present }\end{array}$ & $\begin{array}{c}\text { Complications } \\
\text { Absent }\end{array}$ & Total \\
\hline $15-24$ yrs. & $5(4.81 \%)$ & $2(1.92 \%)$ & $7(6.73 \%)$ \\
\hline $25-34$ yrs. & $9(8.65 \%)$ & $2(1.92 \%)$ & $11(10.58 \%)$ \\
\hline $35-44$ yrs. & $11(10.58 \%)$ & $11(10.58 \%)$ & $22(21.15 \%)$ \\
\hline 45 - 54 yrs. & $13(12.50 \%)$ & $9(8.65 \%)$ & $22(21.15 \%)$ \\
\hline $55-64$ yrs. & $17(16.35 \%)$ & $5(4.81 \%)$ & $22(21.15 \%)$ \\
\hline $65-74$ yrs. & 8 (7.69 \%) & $4(3.85 \%)$ & $12(11.54 \%)$ \\
\hline$\geq 75$ yrs. & $5(4.81 \%)$ & $3(2.88 \%)$ & $8(7.69 \%)$ \\
\hline Total & $68(65.38 \%)$ & $36(34.62 \%)$ & $104(100 \%)$ \\
\hline$\chi 2$-value & \multicolumn{3}{|c|}{$5.52, P=0.47, N S, P>0.05$} \\
\hline
\end{tabular}

In this study conducted on 104 patients, 40 out of 62 male patients and 28 out of 42 female patients developed postoperative complications whereas 22 out of 62 male patients and 14 out of 42 female patients developed no post-operative complications.
In present study, out of 104 patients, 7 patients belonged to age group of 15 - 24 years (the youngest age group) and 8 patients were $\geq 75$ years (the oldest age group). The age group of 35 - 44, 45 - 54 \& 55 - 64 years had same number of patients in age criteria. Age group 55 - 64 years showed the greatest number of patients (17) having complications.

\begin{tabular}{|cccc|}
\hline $\begin{array}{c}\text { Type of } \\
\text { Diagnosis }\end{array}$ & $\begin{array}{c}\text { Complications } \\
\text { Present }\end{array}$ & $\begin{array}{c}\text { Complications } \\
\text { Absent }\end{array}$ & Total \\
Benign & $50(48.08 \%)$ & $23(22.12 \%)$ & $73(70.19 \%)$ \\
Malignant & $18(17.31 \%)$ & $13(12.50 \%)$ & $31(29.81 \%)$ \\
Total & $68(65.38 \%)$ & $36(34.62 \%)$ & $104(100 \%)$ \\
$\chi 2$-value & \multicolumn{4}{c}{1.04, P-value $=0.30$, Not Significant } \\
\hline \multicolumn{4}{|c}{ Table 5. Type of Diagnosis and Complications } \\
\hline
\end{tabular}

In the present study, 50 out of 73 patients with benign diseases developed complications and 18 out of 31 patients with malignant diseases developed complications.

\begin{tabular}{|ccc|}
\hline $\begin{array}{c}\text { Pre-0p Total Albumin } \\
\text { (g / dL) }\end{array}$ & No. of Patients & Percentage \\
$<3.5$ & 44 & 42.31 \\
$3.5-4.5$ & 57 & 54.81 \\
$>4.5$ & 3 & 2.88 \\
Total & 104 & 100 \\
Mean \pm SD & $3.55 \pm 0.60$ \\
\hline \multicolumn{2}{|c|}{ Table 6. Distribution of Pre-Operative Albumin Level } \\
\hline
\end{tabular}

In present study, out of 104 patients, 44 patients had hypoalbuminaemia $(<3.5 \mathrm{~g} / \mathrm{dL})$ pre-operatively whereas the majority of the patients i.e., $54.81 \%$ (57) had preoperative albumin on the lower side (3.55 g / dL) of the normal range (3.5 - $4.5 \mathrm{~g} / \mathrm{dL})$.

\section{DISCUSSION}

\section{Age}

In our prospective observational study of 104 patients, it was observed that the mean age of presentation was $48.19 \pm 15.60$ (15 - 87 years), the youngest patient being 15 years old and oldest patient being 87 years old. According to a study conducted by Alberti et al. ${ }^{6} \mathrm{~A}$ total of 100 patients were observed. It was observed that the mean age of presentation was $51.17 \pm 12.2$ years. Youngest patient being of 18 years of age and oldest patient being 89 years of age. TR Bhandari et al. ${ }^{7}$ on a total of 106 patients observed that, the mean age of presentation was 50 years with youngest patient being of 23 years of age and oldest patient being 81 years of age. Nakano et al. ${ }^{8}$ on 196 patients observed that the mean age of patients was 68 years with youngest patient being of 38 years of age and oldest patient being 87 years of age.

\section{Gender Distribution}

In our study, it was observed that out of 104 cases studied 62 $(59.62 \%)$ were male patients and 42 (40.38\%) were female patients. The gender profiling showed a male to female ratio of 1.47:1. Showing male preponderance. Bhuyan K et al. ${ }^{9}$ on 110 patients observed that, 85 (77\%) were males as compared to $25(22 \%)$ patients were females. The male to female ratio was 3.4:1, showing male preponderance. In a study conducted by Bhagvat VM et al. ${ }^{10}$ on 100 patients, 54 patients (54\%) were males and 46 patients (46\%) were females. The male to 
female ratio was 1.17: 1 , showing negligible difference between the gender distribution. Kumar SV et al. ${ }^{11}$ conducted a study involving 190 patients. It was observed that 117 (61.5 $\%)$ patients were males as compared to 73 (38.5\%) patients who were females. Male preponderance was seen in this study.

\section{Gender Wise Distribution with Presence of Complications}

In the present study conducted on 104 patients, 40 out of 62 male patients developed postoperative complications whereas 22 male patients did not show any postoperative complications. 28 out of 42 female patients developed postoperative complications whereas 14 female patients developed no post-operative complications. TR Bhandari et al. ${ }^{4}$ on 106 patients observed that complications were present in 19 males out of total 70 males and 15 females out of 36 total females, whereas, complications were absent in 51 males and 21 females. Labgaa I et al. ${ }^{12}$ on 138 patients observed, 60 patients had complications out of which 38 were males and 22 were females. 78 patients had no complications ( 34 males and 44 females). The results are similar to our study.

\section{Preoperative Serum Albumin}

In the current study of 104 patients, it has been observed that, 44 (42\%) patients had preoperative serum albumin levels less than $3.5 \mathrm{gm} / \mathrm{dL}$. Maximum number (57 out of 104, 54 \%) of patients were observed to have normal range of serum albumin levels. Though maximum number of these patients were towards lower limit of this range (3.5 - $4.5 \mathrm{~g} / \mathrm{dL}$ ). Only $3(2.88 \%)$ patients had serum albumin levels more than $4.5 \mathrm{~g}$ / dL. The mean preoperative serum albumin level value being $3.55 \mathrm{~g} / \mathrm{dL}$ with SD of \pm 0.60 . More than $50 \%$ of complications were seen in group with preoperative serum albumin $<3.5 \mathrm{~g} /$ dL. Kumar SV et al. ${ }^{11}$ in 2019 , observed that out of 190 patients included in the study, 120 (63\%) patients had preoperative serum albumin $<3.5 \mathrm{~g} / \mathrm{dL}$ whereas $70(37 \%)$ patients had serum albumin $\geq 3.5 \mathrm{~g} / \mathrm{dL}$. More than $90 \%$ of complications were seen in group with preoperative serum albumin $<3.5 \mathrm{~g} /$ dL. In a recent study of 2016 conducted by Bhuyan $\mathrm{K}$ et al,11 out of 110 patients observed in the study, it was noted that 77 (70\%) patients had serum albumin $<3.2 \mathrm{~g} / \mathrm{dL}$ whereas rest of the patients had serum albumin $\geq 3.2 \mathrm{~g} / \mathrm{dL}$. Out of all the complications seen in the study, $90 \%$ complications were seen in patients having serum albumin $<3.2 \mathrm{~g} / \mathrm{dL}$. A prospective study on 106 patients was conducted by Trinbhuvan university Teaching Hospital, Kathmandu, Nepal for a period from July 2012 to June 2013 by TR Bhandari et al. ${ }^{7}$ the study concluded that 70 patients had preoperative serum albumin $\geq$ $3.5 \mathrm{~g} \mathrm{/} \mathrm{dL} \mathrm{(non-hypoalbuminaemic} \mathrm{group)} \mathrm{whereas} 36$ patients had preoperative serum albumin < $3.5 \mathrm{~g} / \mathrm{dL}$ (hypoalbuminaemic group). Mean serum albumin being $3.7 \mathrm{~g}$ / $\mathrm{dL}$ in group with pre-operative serum albumin $\geq 3.5 \mathrm{~g} / \mathrm{dL}$ whereas mean serum albumin in group with serum albumin $>$ $3.5 \mathrm{~g} / \mathrm{dL}$ was $3.2 \mathrm{~g} / \mathrm{dL}$.

\section{CONCLUSIONS}

Preoperative serum albumin plays a vital role in determining postoperative outcome of a patient undergoing major surgery.
The course of the outcome can very well be altered by intravenous infusion of exogenous albumin and by increasing protein intake once patient is allowed to take meals per-orally.

Though serum albumin is clearly indicated to play a vital role, its role is in conjugation to other vital nutritional factors which play a role in recovery of postoperative patients. So, a study which takes in to consideration a bigger population can very well and more accurately determine the role of serum albumin in the patients.

Data sharing statement provided by the authors is available with the full text of this article at jemds.com.

Financial or other competing interests: None.

Disclosure forms provided by the authors are available with the full text of this article at jemds.com.

\section{REFERENCES}

[1] Peters T. All about albumin: biochemistry, genetics, and medical applications. $1^{\text {st }}$ edn. Academic Press 1995.

[2] Moman RN, Gupta N, Varacallo M. Physiology, Albumin. StatPearls [Internet]. Treasure Island (FL): StatPearls Publishing 2021.

[3] Levitt DG, Levitt MD. Human serum albumin homeostasis: a new look at the roles of synthesis, catabolism, renal and gastrointestinal excretion, and the clinical value of serum albumin measurements. Int J Gen Med 2016;9:229-55.

[4] Baron RB. Nutrition - assessment of nutritional status. In: Current medical diagnosis and treatment. McGraw-Hill Medical 2006: p. 1263.

[5] Gassa A, Borghardt JH, Maier J, et al. Effect of preoperative low serum albumin on postoperative complications and early mortality in patients undergoing transcatheter aortic valve replacement. J Thorac Dis 2018;10(12):676370.

[6] Alberti LR, Petroianu A. Importance of the evaluation of serum albumin concentration in postoperative period of patients submitted to major surgeries. ABCD. Arquivos Brasileiros de Cirurgia Digestiva (São Paulo) 2010;23(2):86-9.

[7] Bhandari TR, Shahi S, Bhandari RS, et al. Preoperative serum albumin level as a predictor of perioperative outcome in patient undergoing major gastrointestinal surgery. Journal of Society of Surgeons of Nepal 2016;19(2):13-20.

[8] Nakano Y, Kitago M, Shinoda M, Yagi H, et al. Prognostic significance of the postoperative level and recovery rate of serum albumin in patients with curatively resected pancreatic ductal adenocarcinoma. Mol Clin Oncol 2019;11(3):270-8.

[9] Bhuyan K, Das S. Preoperative serum albumin level as independent predictor of surgical outcome in acute abdomen. International Surgery Journal 2016;3(1):277-9.

[10] Bhagvat VM, Ghetla S, Shetty T, et al. Role of serum albumin and body mass index as predictors of postoperative morbidity and mortality in elective major abdominal surgeries. International Surgery Journal 2016;4(1):91-6.

[11] Kumar S, Prakash DG, Pottendla VK. Preoperative serum albumin level as a predictor of surgical complications 
after emergency abdominal surgery. International Surgery Journal 2019;6(2):361-4.

[12] Labgaa I, Joliat GR, Kefleyesus A, et al. Is postoperative decrease of serum albumin an early predictor of complications after major abdominal surgery? A prospective cohort study in a European centre. BMJ open 2017;7(4):e013966. 